\title{
PB/PB SINGLE-ZIRCON DATING OF PALEOPROTEROZOIC CALC-ALKALINE/ ALKALINE MAGMATISM IN THE SOUTHEASTERN SÃO FRANCISCO CRATON REGION, BRAZIL
}

\section{HANNA JORDT-EVANGELISTA ${ }^{1}$, GUILHERME GRAVINA PERES ${ }^{1}$ AND MOACIR JOSÉ BUENANO MACAMBIRA ${ }^{2}$}

\begin{abstract}
Two chemically and petrographically distinct intrusive bodies (a calc-alkaline trondhjemite and an alkaline quartz-syenite cut by granitic aplites) occur in the vicinity of Piranga (Minas Gerais State), near the southeastern border of the São Francisco craton, Brazil. They intrude the Rio das Velhas greenstone belt and the Mantiqueira complex, both of Archean age. Both intrusive bodies are variably deformed and mylonitized. Age determinations using the $\mathrm{Pb} / \mathrm{Pb}$ single-zircon evaporation method yielded Paleoproterozoic ages for the emplacement/ crystallization of the trondhjemite $(2058 \pm 10 \mathrm{Ma})$, quartz-syenite $(2036 \pm 4 \mathrm{Ma})$, as well as the younger aplites $(2012 \pm 8 \mathrm{Ma})$. These ages allow us to interpret the calc-alkaline as well as the alkaline magmatism as manifestations of the Transamazonian event in the southeastern São Francisco craton region. Furthermore, the calc-alkaline trondhjemite is interpreted to have intruded during compressional deformation, while the alkaline quartz-syenite and its aplitic differentiates are post-orogenic, possibly extension-related. In terms of the $\mathrm{Rb} v s$. (Y $+\mathrm{Nb}$ ) contents, the trondhjemite plots in the field of volcanic arc granites, whereas the syenite and the aplites plot in the field of post-collision granites. The mylonitic overprinting of the syenite and the trondhjemite is also Paleoproterozoic, as deduced from the $2012 \pm 8 \mathrm{Ma}$ age of the undeformed younger aplitic dykes which cut the syenite. It is likely that this alkaline magmatism correlates with a Paleoproterozoic post-collisional magmatic event well documented in the Transamazonian mobile belts of the northern São Francisco craton.
\end{abstract}

Keywords: geochronology, Transamazonian, alkaline, syenite, trondhjemite, Quadrilátero Ferrífero, São Francisco craton

\section{INTRODUCTION}

Calc-alkaline rocks generated during compressional deformation associated with the $2100 \mathrm{Ma}$ Transamazonian fold-thrust belt have been described in many localities in the Quadrilátero Ferrífero (Noce 1995, Pires \& Barbosa 1993, also see review of geochronological data in Endo 1997). Conversely, alkaline rocks are scarce in the region and their chronology is usually inferred (Pinto 1995). This paper discusses the results of $\mathrm{Pb} / \mathrm{Pb}$ singlezircon dating of alkaline as well as calc-alkaline rock located in the southeastern vicinity of the São Francisco craton (Fig. 1), which is referred here as the southeastern São Francisco craton region. The results are also important because alkaline as well as calc-alkaline rocks are important paleogeographic indicators, which could contribute to a better understanding of the evolution of the Transamazonian orogen in the studied area.

GEOLOGICAL SETTING Trondhjemite or quartz syenite bodies occur in the southeastern São Francisco craton region, in the vicinity

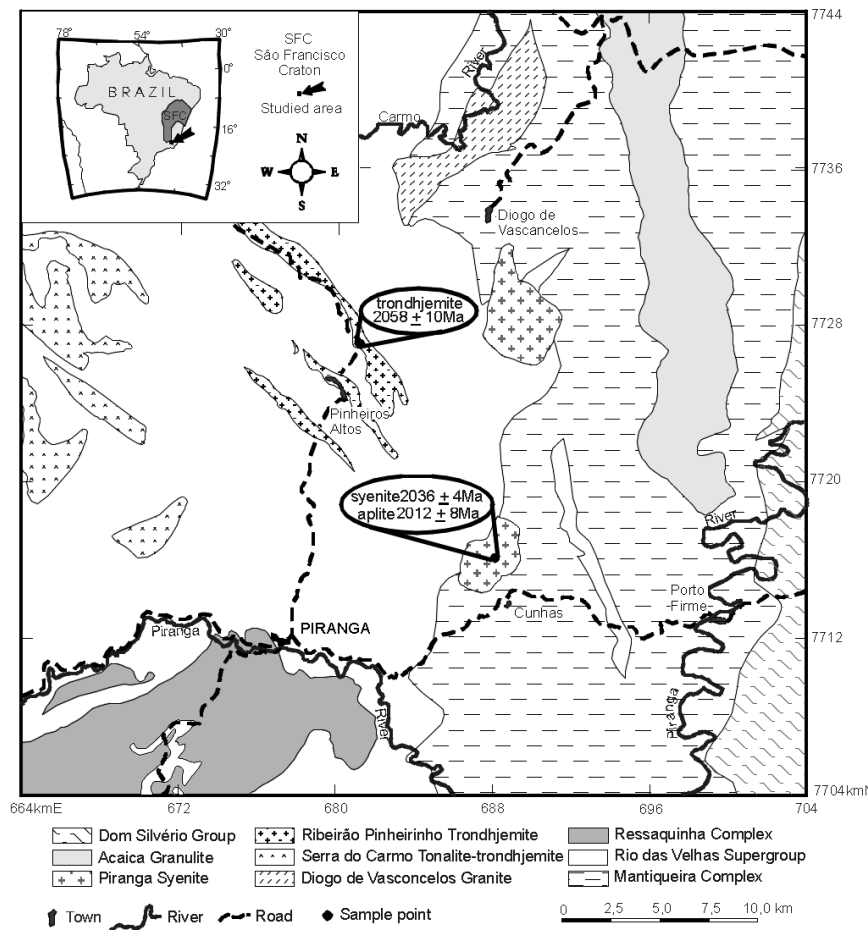

Figure 1 - Geological map of the Piranga area (modified after Raposo 1991) and location of dated outcrops. of the town of Piranga, Minas Gerais (Fig. 1). The rock bodies intruded lithologies of the Rio das Velhas greenstone belt and the Mantiqueira gneiss complex, both of Archean age.

The Piranga syenite crops out as two small bodies of about 20 and $40 \mathrm{~km}^{2}$ (Fig. 1; Jordt-Evangelista \& Peres 1997a). Several generations of aplitic rocks, including deformed and undeformed dykes, cut the quartz syenite (Fig. 2a). We collected samples from the undeformed generation for age determination. Mapping of the syenite bodies was greatly improved by the use of a scintillometer, since its soil is usually

\section{A}

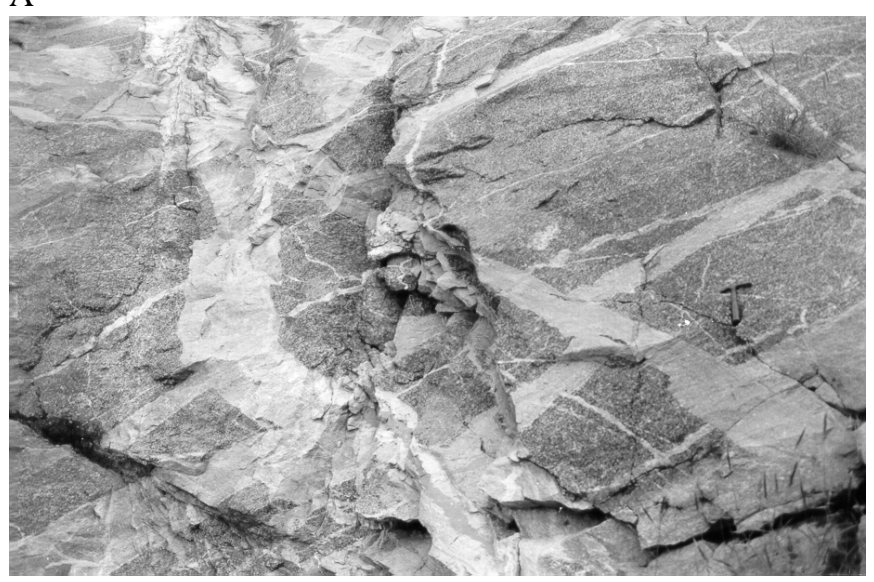

B

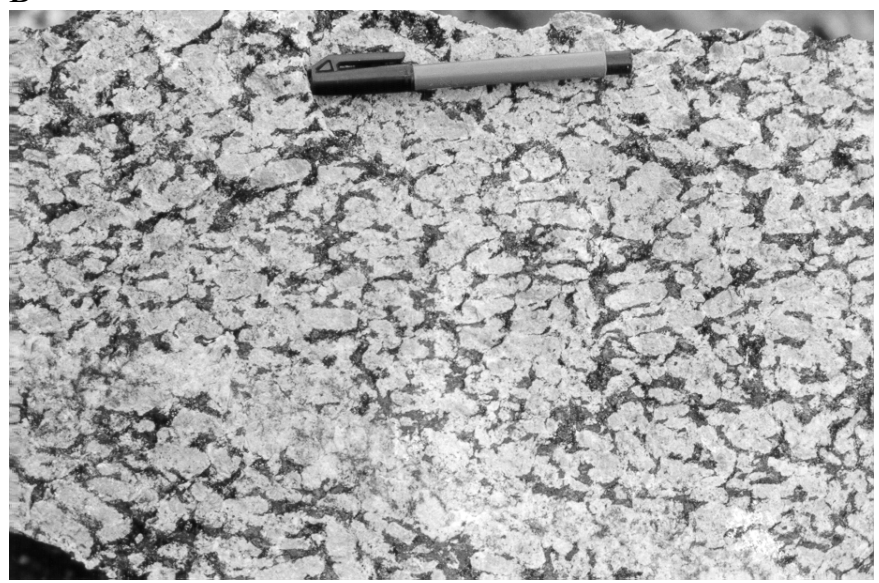

Figure 2 - (A) - Aplitic dykes cutting the Piranga syenite. Notice hammer (left central area of photography) for scale. (B) - Alkali-feldspar rich undeformed Piranga syenite.

1 - Universidade Federal de Ouro Preto, Departamento de Geologia, 35400-000 Ouro Preto, Minas Gerais, Brazil; e-mail: hanna@ degeo.ufop.br 2 - Universidade Federal do Pará, C.P. 1611, 66075-110 Belém, Pará, Brazil 
more radioactive ( 200 to $500 \mathrm{cps}$, mean values around $300 \mathrm{cps}$ ) than the derived from the surrounding gneisses of the Mantiqueira complex (40 - 150cps), the Ribeirão Pinheirinhos trondhjemite (50 - 100cps) or from rocks of the Rio das Velhas greenstone belt (garnet schist 30 $50 \mathrm{cps}$, talc schist 10 - 30cps, amphibolite $30-50 \mathrm{cps}$ ). The aplites are even more radioactive than the syenite, reaching values of $800 \mathrm{cps}$.

The Ribeirão Pinheirinhos trondhjemite (originally classified as a granite-granodiorite in the geological map of Raposo 1991) is composed of several small NW-SE trending bodies (Raposo 1991, Peres \& Abib 1997) which crop out relatively close to the syenite (Fig. 1). The sample dated belongs to a body of about $12 \mathrm{~km}^{2}$ located only $5 \mathrm{~km}$ west of the northern syenite.

\section{PETROGRAPHY AND GEOCHEMISTRY}

The Ribeirão

Pinheirinhos trondhjemite is a leucocratic, medium-grained rock with a penetrative foliation which is deflected around older phenocrysts (= porphyroclasts) of plagioclase (oligoclase) and lenses of quartz. The trondhjemite has the following mean mineralogical composition: plagioclase $50 \mathrm{vol} \%$, quartz $35 \%$, microcline $5 \%$, biotite $5 \%$, accessory allanite, apatite, zircon, titanite, opaque minerals, fluorite, and secondary white mica, carbonate, epidote and chlorite $5 \%$ Strongly mylonitized bands impart a gneissosity to the trondhjemite.

The Piranga quartz syenite is a medium to coarse-grained rock. It is variably sheared, being locally transformed into a gneiss with melanocratic bands. The least deformed portions are composed of abundant tabular phenocrysts of alkali-feldspar (Fig. 2b). The alkalifeldspar, usually surrounded by a mantle of fine-grained albite, is perthitic to mesoperthitic. The matrix is composed of granoblastic microcline, albite, and quartz, and clusters of mafic minerals. The mafic minerals are light green diopside (partially replaced by actinolite), strongly pleochroic, bluish green calcic amphibole (ferroan paragasitic hornblende), greenish brown biotite, and accessory titanite apatite, allanite, opaque minerals (iron oxides and ilmenite), and zircon. Secondary minerals include light green amphibole (actinolite), epidote, carbonate and chlorite. The typical modal composition is: alkali-feldspar $80-90$ vol\%, quartz $0-10 \%$ and mafic minerals $10-20 \%$.

The aplite from the dykes has the mineralogical composition of an alkali-feldspar granite, consisting of granoblastic microcline (50vol\%), albite (20\%), quartz (25\%) and 5\% of mafic minerals (diopside, calcic amphibole, biotite, apatite, zircon, allanite, opaque minerals and carbonate).

Geochemically, the trondhjemite is calc-alkaline, plotting in the field of volcanic arc granites of Pearce (1984; Fig. 3). The alkaline rocks plot within the field of post-collision granites of Pearce (1996; Fig. 3). The CIPW norm shows that the syenite is mostly quartznormative, with $\mathrm{Q}$ reaching up to 15 weight $\%$. However, samples rich in alkali-feldspar phenocrysts have $\mathrm{Q}=0$, being olivine and acmite normative, as well as peralkaline in the sense of Le Maitre (1989), with molar $\left(\mathrm{Na}_{2} \mathrm{O}+\mathrm{K}_{2} \mathrm{O}\right) / \mathrm{Al}_{2} \mathrm{O}_{3}$ greater than 1 .

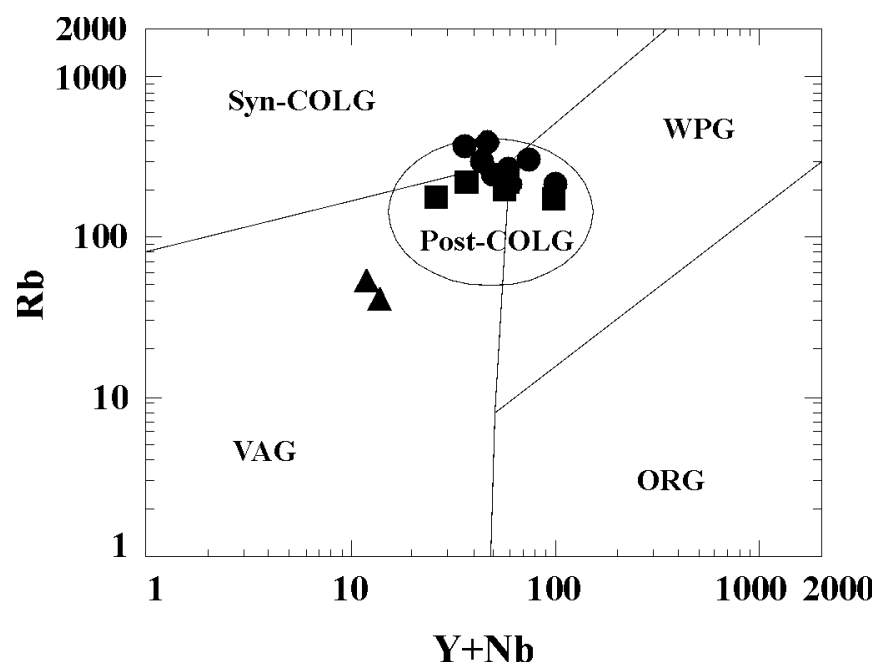

Figure 3 - Rb vs. Y+Nb diagram of Pearce et al. (1984) and Pearce (1996) for the Ribeirão Pinheirinhos trondhjemite (triangle), Piranga syenite (circle) and aplitic dikes (square). Syn-COLG and Post-COLG: Syn- and Post-collision Granites; WPG: Within Plate Granites; VAG: Volcanic Arc Granites; ORG: Ocean Ridge Granites.
GEOCHRONOLOGY Single-zircon age determination by stepwise $\mathrm{Pb}$ evaporation method usually yields results very similar to the ages obtained by the zircon U/Pb method (Kober 1987, Andsdell \& Kyser 1991). Therefore, the apparent ${ }^{207} \mathrm{~Pb} /{ }^{206} \mathrm{~Pb}$ ages may be interpreted as the crystallization age of the zircon. However, these ages are less exact than the $\mathrm{U} / \mathrm{Pb}$ method and should be considered as the minimum crystallization age of the analyzed zircons (Gaudette et al. 1998).

The least magnetic zircon fractions were chosen for geochronology. The analyzed crystals are prismatic, with length/width ratios varying between $4: 1$ and $2: 1$, transparent to translucent, colorless or faintly colored in shades of brown. Microfractures or translucent borders indicative of incipient metamictic alteration were observed in a few crystals.
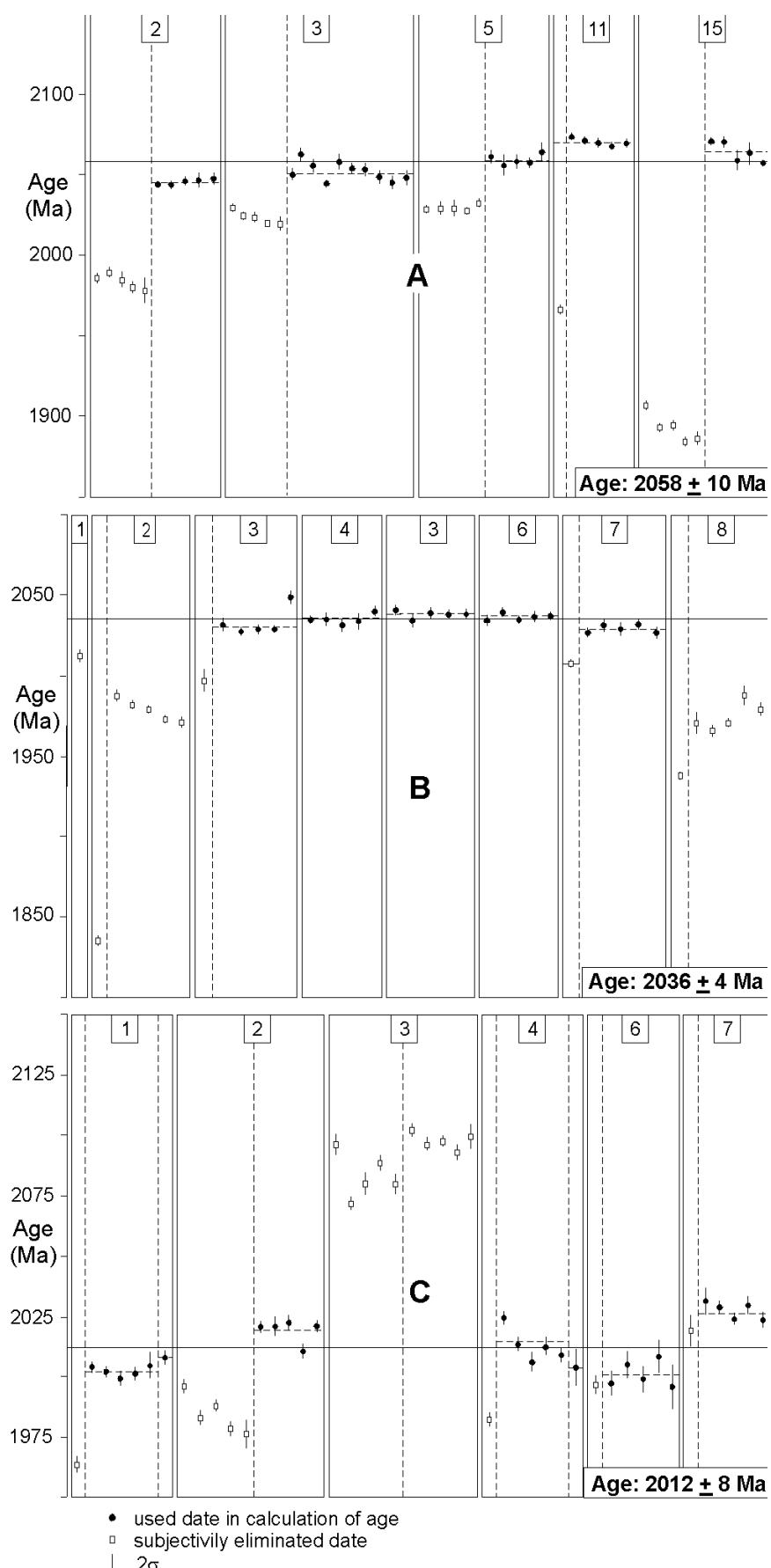

Figure 4 - Age vs. evaporation steps diagram for zircon crystals from the Ribeirão Pinheirinhos trondhjemite $(A)$, Piranga syenite $(B)$ and Piranga aplitic dyke $(C)$ 
The following results were obtained:

- Ribeirão Pinheirinhos trondhjemite - fifteen zircon crystals were analyzed, four did not contain enough $\mathrm{Pb}$ for analysis and six were discarded because of discrepant results. The high temperature analyses of five crystals resulted in a crystallization age of $2058 \pm$ $10 \mathrm{Ma}$ (Fig. 4A).

- Piranga syenite - eight zircon crystals were selected but three of them did not contain enough $\mathrm{Pb}$ for analysis The high temperature analyses of five crystals resulted in a crystallization age of $2036 \pm$ 4Ma (Fig. 4B).

- Piranga aplite, undeformed - seven zircon crystals were selected but one of them did not contain enough $\mathrm{Pb}$ for analysis. The high temperature analyses of six crystals resulted in a crystallization age of $2012 \pm 8 \mathrm{Ma}$ (Fig. 4C).

DISCUSSION AND CONCLUSIONS Whereas calc-alkaline rocks are considered typical of convergent margin setting, alkaline magmatic provinces are traditionally considered as anorogenic. The anorogenic character has been used to typify A-granites. Little attention has been paid to characteristics of late- to post-orogenic alkaline massifs compared with classical non-orogenic massifs. A shift from calc-alkaline to alkaline magmatism in the Alpine-Mediterranean belt was described by Bonin (1988), where alkaline complexes are emplaced at the same sites as previous calc-alkaline bodies at times when orogenic events were not yet completed, characterizing a shift from a typical orogenic context to an anorogenic context. Bonin (1988) explains the transition of the magmatic episodes as resulting from the evolution of the behavior of water: calc-alkaline magmas are produced when water is available at the melting zones and alkaline magmas if water is no longer available at the melting zones.

Pearce (1996) improved his earlier $\mathrm{Rb} v s$. $(\mathrm{Y}+\mathrm{Nb})$ diagram (Pearce et al. 1984) for discriminating the tectonic setting of granites by introducing a field for post-collision granites. In this diagram, the studied trondhjemite plots in the volcanic arc granite field and the syenite and aplites in the post-collision granite field (Fig. 3). Pearce (1996) emphasizes that the post-collision granites are the most difficult to classify on the basis of chemistry as they have the greatest range of sources, such as enriched mantle associated with extensive crustal interaction.

The Quadrilátero Ferrífero lies in the foreland of the Paleoproterozoic Transamazonian orogen generated during a collisional event leading to a 2100Ma fold-thrust belt (Alkmim \& Marshak 1998). The magmatic arcs, the accreted terranes, and the associated suture are supposed to lie to the east and southeast of the margin of the São Francisco craton, more precisely in the Coastal Mobile belt, being extensively overprinted by the Brasiliano (Pan African) event. In fact, relicts of Transamazonian rocks can be found in the Coastal Mobile Belt (Machado et al. 1996). Alkmim \& Marshak (1998) also noticed that there is an apparent lack of large volumes of Transamazonian-age granitoids. The calc-alkaline and alkaline rocks dated as Transamazonian in this study lie within regions composed of Archean crust of the São Francisco craton which were later reworked during Transamazonian events. The fact that Transamazonian magmatism is found in Piranga, near the southeastern border of the Quadrilátero Ferrífero, means that the production of magma during this orogeny was more widespread than previously recognized.

Syenites as well as calc-alkaline rocks attributed to the Paleoproterozoic are also found farther south and southwest, as for example the Matola and Ubari alkaline complexes (Brandalise et al. 1992, Pinto 1995), the Alto Maranhão tonalite, dated at 2124Ma by Noce (1995) and many granites (Pires \& Barbosa 1993). Many small syenite bodies with ages between 2100 and $1800 \mathrm{Ma}$ are aligned over a $1000 \mathrm{~km}$ length along the NS-trending Transamazonian belts in Bahia, northern Brazil (Conceicão 1993). It is possible that the Transamazonian oversaturated alkaline magmatism of Minas Gerais was generated in the same magmatic event as the syenites found in Bahia and perhaps belong to the same N-S belt of post-collisional Transamazonian alkaline magmatism.

Another conclusion that can be drawn from this study concerns the age of the deformation that affected the dated plutonic rocks and part of the aplites. Because the dated aplitic dike is undeformed, its crystallization age of $2012+/-8 \mathrm{Ma}$ indicates that the deformation of the syenite and trondhjemite must be older. This suggests that the syenite and trondhjemite bodies were intruded during Transamazonian deformation, as previously deduced from the observed high temperature recrystallization fabrics (Jordt-Evangelista \& Peres 1997b).

Acknowledgments To F.F. Alkmim for helpful discussions and review of the earlier manuscript, D. Cunningham for review of the English text, C. Dürkop for chemical analyses, K. Fusikawa for lending the scintillometer. To two anonymous referees of RBG for the critical analysis of the manuscript.

\section{References}

Alkmim F.F., Marshak S. 1998. Transamazonian Orogeny in the Southern São Francisco Craton Region, Minas Gerais, Brazil: evidence for Paleoproterozoic collision and collapse in the Quadrilátero Ferrífero. Precambrian Research, 90:29-58

Andsdell K.M., Kyser T. K. 1991. Plutonism, deformation and metamorfism in Proterozoic Flin Flon Greenstone belt Canadá. Limits on timing by the zircon Pb evaporation technique. Geology, 18:518-521

Bonin B. 1988 From orogenic to anorogenic environments: evidence from associated magmatic episodes. Schweiz. Mineral. Petrogr. Mitt., 68:301-311

Brandalise L.A., Pinto C.P., Viana H.S., Bruno E.M. Zucchetti, M. 1992. Província alcalina da Mantiqueira, Serra da Mantiqueira, MG. Revista Escola de Minas (REM), 45:179-180, Ouro Preto, Brazil

Conceição H. 1993. Sienitos do Estado da Bahia: um epítome e interpretação à luz do conhecimento atual. In: SBG/Núcleo Bahia/Sergipe, Simpósio do Cráton do São Frannhecimento atual. In: SBG/Núcleo
cisco, 2, Salvador, Anais, 52-55

Endo I. 1997. Regimes Tectônicos do Arqueano e Proterozóico no Interior da Placa Sanfranciscana: Quadrilátero Ferrifero e Áreas Adjacentes, Minas Gerais. Inst. de Geociências, Universidade de São Paulo, São Paulo, Brazil, Doctor Thesis, 243p.

Gaudette H.E., Lafon J.M., Macambira M.J.B., Moura C.A.V., Scheller T. 1998 Comparison of single filament $\mathrm{Pb}$ evaporation/ionization zircon ages with conventional U-Pb results: examples from Precambrian of Brazil. Journal of South Amer. Earth Sci., 11:351-363

Jordt-Evangelista H., Peres G.G. 1997a. O maciço sienítico de Piranga, Minas Gerais. In SBG/ Núcleo Minas Gerais, Simpósio de Geologia de Minas Gerais, 9, Ouro Preto, Boletim 14:110-112

Jordt-Evangelista H., Peres G.G. 1997b. O papel da deformação na geração de um gnaisse ortoderivado. In: SBG/ Núcleo Brasília, Simpósio Nacional de Estudos Tectônicos (SNET), 6, Pirenópolis, Anais, 200-202

Kober B. 1987. Single grain evaporation combined with $\mathrm{Pb}$ emitter bedding ${ }^{207} \mathrm{~Pb} /{ }^{206} \mathrm{~Pb}$ investigations using thermal ion mass spectrometry and implications to zirconology. investigations using thermal ion mass
Contr. Mineral. Petrol., 96:63-71
Le Maitre R.W. (ed.) 1989. A Classification of Igneous Rocks and Glossary of Terms. Oxford, Blackwell, 193p

Machado N., Valladares C., Heilbron M., Valeriano C. 1996. U-Pb geochronology of the central Ribeira belt (Brazil) and implications for the evolution of the Brazilian Orogeny. Precambrian Research, 79:347-361

Noce C.M. 1995. Geocronologia dos Eventos Magmáticos, Sedimentares e Metamórficos na Região do Quadrilátero Ferrífero, Minas Gerais. Inst. de Geociências, Universidade de São Paulo, São Paulo, Brazil, Doctor Thesis, 128p.

Pearce J. 1996. Sources and settings of granitic rocks. Episodes, 19:120-125

Pearce J., Harris N.B.W. , Tindle A. G. 1984. Trace element discrimination diagrams for the tectonic interpretation of granitic rocks. Journal of Petrology, 25:956-983

Peres G.G., Abib M.M.S. 1997. Geologia da região de Pinheiros Altos, Município de Piranga, MG. Departamento de Geologia, Universidade Federal de Ouro Preto, Piranga, MG. Departamento de Geologia, Un

Pinto C.P 1995. Petrologia de Rochas Alcalinas, Cálcio-alcalinas e Toleíticas da Serra da Mantiqueira em Minas Gerais, Brasil. Instituto de Geociências, Universidade Federal de Minas Gerais, Brazil, Master Thesis, 143p.

Pires F.R.M., Barbosa M.I.M. 1993. O limite meridional do Cráton São Francisco e o posicionamento de granitos colisionais. In: SBG/ Núcleo Bahia/Sergipe, Simpósio do Cráton do São Francisco, 2, Salvador, Anais, 33-38

Raposo F.O. 1991. Carta Geológica da Folha Rio Espera (SF.23-X-B-IV), Estado de Minas Gerais. Programa de Levantamentos Geológicos Básicos do Brasil, DNPM/ CPRM, 1:100.000, Belo Horizonte.

Contribution IGC-182 Received March 1,2000 Accepted for publication May 1, 2000 